\title{
Weather conditions affect spring and autumn migration of Siberian leaf warblers
}

\author{
László Bozó ${ }^{1 *} \mathbb{D}$, Tibor Csörgő² and Wieland Heim³
}

\begin{abstract}
Background: Weather effects on bird migration are well-studied among Passerines moving from Europe to Africa or within the American flyway systems. However, little is known about the weather impact on songbirds migrating along the East Asian flyway. Our study aims to describe the effects of various weather elements on the migration of four species of leaf warblers by using bird ringing data from a stopover site in Far East Russia.

Methods: We determined the migration periods for each species and included maximum temperature, precipitation, air pressure, wind speed and wind direction in general linearized mixed models to predict the number of migrating birds.

Results: We found strong impacts of weather variables on the number of trapped warblers during spring and autumn migration. Preferred or avoided weather conditions were similar among the studied species. All species seem to migrate preferably during warm, calm days without precipitation. A positive effect of tail winds was only confirmed in autumn, but in spring, most birds were trapped during crosswinds (eastern or western winds).

Conclusion: The studied species might exhibit a loop migration, leading to a more longitudinal (from east to west) migration pattern in our study area during spring. Relationships between weather variables and the number of migrating individuals were much stronger during autumn. We argue that birds during spring migration would continue migration under sub-optimal conditions, as a result of strong competition to arrive earliest on their breeding grounds.
\end{abstract}

Keywords: Phylloscopus, Bird migration, Weather, East Asian flyway

\section{Background}

During migration birds face many challenges, including unfamiliar foraging and refuge habitats, resulting in a much higher rate of mortality during migration than during other seasons of the year. Weather may significantly affect a bird's decision to initiate migration, the course and pace of migration, and its survival during migration (Miller et al. 2016). Favourable weather conditions for migration enhance the orientation of birds, reduce the use of energy for flying and increase the speed of migration (Emlen 1975; Bloch and Bruderer 1982; Gauthreaux 1982; Akesson 1993; Liechti 2006; Shamoun-Baranes et al. 2017). According to the majority of the studies,

\footnotetext{
*Correspondence: bozolaszlo91@gmail.com

${ }^{1}$ Department of Systematic Zoology and Ecology, Eötvös Loránd University, Pázmány Péter sétány 1/C, Budapest 1117, Hungary Full list of author information is available at the end of the article
}

most migrations take place in windless, clear, anticyclonic weather conditions without precipitation, or with support of tail winds (Alerstam 1990; Gyurácz et al. 1997, 2003; Bruderer and Boldt 2001; Erni et al. 2002). Favourable conditions can occur in different macrosynoptic weather situations (Kerlinger et al. 1989). Atmospheric conditions are the primary extrinsic factors influencing decisions regarding migratory flights, particularly over water bodies with limited opportunities to land (Richardson 1990). Wind plays a critical role, affecting departure date and migratory directions, routes, speeds, flight durations, energy consumption and the crossing of ecological barriers (Cochran and Kjos 1985; Weber and Hedenström 2000; Pennycuick and Battley 2003; Cochran and Wikeski 2005; Bowlin and Wikelski 2008; ShamounBaranes and van Gasteren 2011; Bulte et al. 2014; Gill et al. 2014). Decisions to depart stopover sites and initiate 
flight over large water bodies are also influenced by barometric pressure, temperature, relative humidity, and short-term trends in these variables, which are indicative of synoptic weather patterns and may provide information about future weather conditions (Able 1972; Newton 2008). In case of tail winds, birds are capable of flying longer distances while exerting less energy (Emlen 1975; Bloch and Bruderer 1982; Gauthreaux 1982, 1991; Alerstam 1990; Richardson 1990; Bruderer and Boldt 2001). Weather conditions that delay migration include cloudy skies, poor visibility, strong winds (head winds and cross winds), and warm or occluded fronts (Akesson 1993; Pyle et al. 1993).

The relationship between the migration of birds and various weather elements or atmospheric conditions was studied mostly in Europe (Alerstam 1978, 1990; Akesson 1993; Erni et al. 2002; Schaub et al. 2004; Van Belle et al. 2007; Arizaga et al. 2011) and North America (Able 1973; Emlen 1975; Kerlinger et al. 1989; Deppe et al. 2015; Woodworth et al. 2015). However, few studies are available for the migration of Siberian species, providing only limited information on autumn and spring migration phenology of some species (Williams 2000; Bozó and Heim 2015, 2016; Bozó et al. 2016, 2017; Sander et al. 2017), or focussing on their (irregular) occurrences in Europe (Rabøl 1969; Baker 1977; Folvik 1992; Berthold 1996; Thorup 1998, 2004; Phillips 2000; Gilroy and Lees 2003; Krüger and Dierschke 2004; Harrop 2007; De Juana 2008; Jiguet and Barbet-Massin 2013). However, to understand the causes of the European vagrancies, information on migration phenology of this species related to local weather is necessary. Expanding this knowledge is not only important in understanding the causes of their vagrancy, but also for perspective conservation measures. Some of the East Asian migrants have declined dramatically (Kamp et al. 2015), and local declines are noted even in common species, e.g. in wintering Yellow-browed Warblers (Phylloscopus inornatus) on Hainan Island (Xu et al. 2017).

This study aims to describe the effects of various weather elements on the numbers of migrating Siberian breeding Phylloscopus warbler species at a stopover site in Far East Russia.

\section{Methods}

The study was carried out within the Amur Bird Project during spring $(2013,2015,2016,2017)$ and autumn (2011-2014) migration at Muraviovka Park along the middle stream of the Amur River in the Russian Far East (Heim et al. 2012). The study site is located $60 \mathrm{~km}$ southeast of the city of Blagoveshchensk $\left(49^{\circ} 55^{\prime} 08.27^{\prime \prime} \mathrm{N}\right.$, $\left.127^{\circ} 40^{\prime} 19.93^{\prime \prime} \mathrm{E}\right)$.
The study periods were the following: in 2011, from 7 September to 15 October; in 2012, from 29 August to 15 October; in 2013, from 25 April to 08 June and from 27 July to 17 October; in 2014, from 25 July to 15 October; in 2015, from 25 April to 10 June; in 2016, from 25 April to 07 June, while in 2017, from 28 April to 08 June. During this period, in total 52 mist-nets were used for the work. Netting sites were not changed within season, however, the sampling effort varied among years (Table 1). The nets were set up in a variety of habitats: homogeneous reed-beds, sedges and grassy swamps interspersed with willows and raspberries, rich shrub-layered mixed forest, very dense scrub and stubble. The work was carried out daily from sunrise to sunset and the nets were checked every hour. In case of storm, heavy wind and rain, nets were closed.

Data analysis was carried out based on 6191 individuals of four species: Yellow-browed Warbler (Phylloscopus inornatus), Dusky Warbler (P. fuscatus), Radde's Warbler (P. schwarzi) and Pallas's Leaf Warbler (P. proregulus) (Table 2). All birds were marked with rings of the Moscow Ringing Centre. Species identifications were based on Svensson (1992) and Brazil (2009). We only included data of first captures and excluded all recaptures.

To analyse the effects of weather for bird migration, we collected the following weather data for every day: minimum and maximum temperature $\left({ }^{\circ} \mathrm{C}\right)$, precipitation $(\mathrm{mm})$, average air pressure $(\mathrm{mb})$, average wind speed (Beaufort scale 0-12), average wind direction (cross winds: $\mathrm{E}$ and $\mathrm{W}$ winds in spring and autumn; tail winds: $\mathrm{N}, \mathrm{NE}$ and NW in autumn and S, SE and SW in spring; head winds: N, NE and NW in spring and S, SE and SW in autumn). Air pressure and precipitation data were gathered from the webpage of World Weather Online (World Weather Online 2017) for the area of Blagoveshchensk, while the remaining data were collected by the ringing teams at Muraviovka Park.

Table 1 Sampling effort between 2011-2017 at the study site (total number of nets $x$ daily mist-netting hours)

\begin{tabular}{lll}
\hline Year & \multicolumn{2}{l}{ Season } \\
\cline { 2 - 3 } & Spring & Autumn \\
\hline 2011 & - & 6161 \\
2012 & - & 14,253 \\
2013 & 9352 & 16,654 \\
2014 & - & 31,235 \\
2015 & 8204 & - \\
2016 & 6710 & - \\
2017 & 7729 & - \\
\hline
\end{tabular}


Table 2 Number of ringed birds for all study species and their migration periods at Muraviovka Park

\begin{tabular}{lcclll}
\hline Species & \multicolumn{2}{l}{ Number of birds } & & & Migration period \\
\cline { 2 - 3 } & Spring & Autumn & & Spring & Autumn \\
\hline Yellow-browed Warbler & 2275 & 1584 & & 26 April-6 June & 26 July-13 October \\
Dusky Warbler & 497 & 1089 & & 29 April-9 June & 26 July-9 October \\
Pallas's Leaf Warbler & 79 & 369 & & 29 April-5 June & 6 September-17 October \\
Radde's Warbler & 81 & 217 & 9 May-8 June & 5 August-26 September \\
\hline
\end{tabular}

The migration periods are species-specific, therefore it was necessary to determine migration periods for each species. On the basis of the daily numbers caught, migration periods were determined for all studied species (Fig. 1). Only days within the migration period were considered in the following models.

General Linear Mixed Models (GLMM) were used to evaluate the weather impact on the number of trapped birds per day. Models were built for each species for both spring and autumn season. Year and Julian day were included as random factors. Minimum temperature was excluded from the models, as it was highly correlated with maximum temperature $(R=0.77, t=30.2$, $\mathrm{df}=722, p<0.001)$. The full models were of the following structure:

the number of birds trapped per day

$$
\begin{aligned}
& \sim \text { temperature }+ \text { precipitation }+ \text { air pressure } \\
& + \text { wind speed }+ \text { wind direction }+1 \mid \text { year }+1 \mid \text { day }
\end{aligned}
$$

Furthermore, we built a model for all four species together, and included species as additional random factor as well. We checked for overdispersion using the dispersion-glmer function of the $\mathrm{R}$ package blmeco. For analysis, $\mathrm{R}$ version 3.4.2 ( $\mathrm{R}$ Core Team 2017) and packages lme4 (Bates et al. 2014) and piecewiseSEM (Lefcheck 2016) were used.

\section{Results}

The migration periods of the four study species are shown in Table 2.

The GLMM for single species explained only a small part of the variability, with higher values during autumn migration $\left(R_{\text {marg }}^{2}: 0.07-0.18\right)$ compared to spring migration $\left(R_{\text {marg }}^{2}: 0.03-0.10\right)$. This was also true for the overall model, including all four species-see Table 3. Much more of the variance was explained by the random factors $\left(R_{\text {cond }}^{2}\right)$ (Table 3$)$.

During spring, the most important factor for all species is temperature, with significantly more birds trapped during warmer days. Furthermore, wind direction is a significant predictor in the overall model and in two out of four species models, with the highest number of birds trapped during cross winds.

In autumn, the number of trapped warblers is negatively affected by precipitation and wind speed, while maximum temperature is positively related with the number of trapped individuals in the overall model and

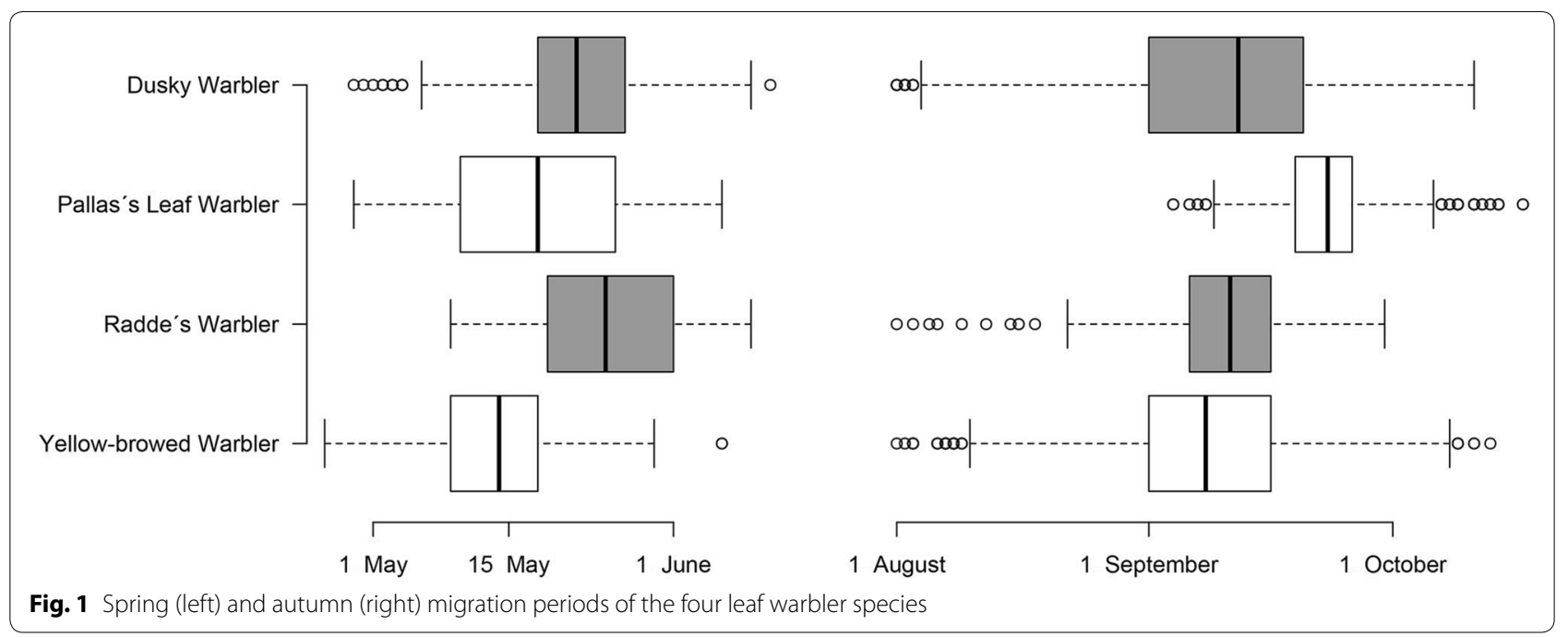


Table 3 Outputs of general linear mixed models

\begin{tabular}{|c|c|c|c|c|c|c|c|c|}
\hline \multirow[t]{2}{*}{ Species } & & \multicolumn{3}{|c|}{ Spring migration } & & \multicolumn{3}{|c|}{ Autumn migration } \\
\hline & & Estimate & $x^{2}$ & $p$ & & Estimate & $x^{2}$ & $p$ \\
\hline \multirow[t]{10}{*}{ ALL } & Temperature & 0.42 & 133.3 & $* * *$ & Temperature & 0.22 & 18.4 & $* * *$ \\
\hline & Precipitation & 0.09 & 8.7 & 0.003 & Precipitation & -0.53 & 121.4 & $* * *$ \\
\hline & Air pressure & -0.10 & 9.4 & 0.002 & Air pressure & -0.25 & 39.3 & $* * *$ \\
\hline & Wind speed & 0.09 & 9.3 & 0.002 & Wind speed & -0.29 & 65.6 & $* * *$ \\
\hline & Wind direction & & 65.8 & $* * *$ & Wind direction & & 54.6 & $* * *$ \\
\hline & Headwind & -0.30 & & & Headwind & -0.39 & & \\
\hline & Crosswind & -0.05 & & & Crosswind & -0.17 & & \\
\hline & Tailwind & -0.72 & & & Tailwind & 0.08 & & \\
\hline & $R_{\text {marg }}^{2}$ & 0.03 & & & $R_{\text {marg }}^{2}$ & 0.12 & & \\
\hline & $R_{\text {cond }}^{2}$ & 0.82 & & & $R_{\text {cond }}^{2}$ & 0.84 & & \\
\hline \multirow[t]{10}{*}{ Dusky Warbler } & Temperature & 0.41 & 17.0 & $* * *$ & Temperature & 0.35 & 16.9 & $* * *$ \\
\hline & Precipitation & 0.09 & 1.0 & 0.321 & Precipitation & -0.50 & 37.7 & $* * *$ \\
\hline & Air pressure & -0.01 & 0.0 & 0.861 & Air pressure & -0.13 & 4.3 & 0.039 \\
\hline & Wind speed & 0.08 & 1.0 & 0.310 & Wind speed & -0.09 & 2.4 & 0.121 \\
\hline & Wind direction & & 17.0 & $* * *$ & Wind direction & & 18.8 & $* * *$ \\
\hline & Headwind & 0.42 & & & Headwind & 0.29 & & \\
\hline & Crosswind & 1.12 & & & Crosswind & 0.53 & & \\
\hline & Tailwind & 0.08 & & & Tailwind & 0.76 & & \\
\hline & $R_{\text {marg }}^{2}$ & 0.09 & & & $R_{\text {marg }}^{2}$ & 0.18 & & \\
\hline & $R_{\text {cond }}^{2}$ & 0.75 & & & $R_{\text {cond }}^{2}$ & 0.84 & & \\
\hline \multirow[t]{10}{*}{ Pallas's Leaf Warbler } & Temperature & 0.40 & 5.2 & 0.022 & Temperature & -0.27 & 2.3 & 0.126 \\
\hline & Precipitation & 0.01 & 0.0 & 0.946 & Precipitation & -0.24 & 2.2 & 0.137 \\
\hline & Air pressure & -0.03 & 0.0 & 0.870 & Air pressure & 0.10 & 0.7 & 0.417 \\
\hline & Wind speed & 0.02 & 0.0 & 0.900 & Wind speed & -0.43 & 13.1 & $* * *$ \\
\hline & Wind direction & & 4.7 & 0.096 & Wind direction & & 6.3 & 0.043 \\
\hline & Headwind & -1.11 & & & Headwind & -2.05 & & \\
\hline & Crosswind & -0.34 & & & Crosswind & -1.74 & & \\
\hline & Tailwind & -1.35 & & & Tailwind & -1.51 & & \\
\hline & $R_{\text {marg }}^{2}$ & 0.09 & & & $R_{\text {marg }}^{2}$ & 0.07 & & \\
\hline & $R_{\text {cond }}^{2}$ & 0.34 & & & $R_{\text {cond }}^{2}$ & 0.71 & & \\
\hline \multirow[t]{10}{*}{ Radde's Warbler } & Temperature & 0.56 & 8.9 & 0.003 & Temperature & 0.38 & 5.9 & 0.016 \\
\hline & Precipitation & 0.00 & 0.0 & 0.993 & Precipitation & -0.45 & 8.5 & 0.004 \\
\hline & Air pressure & 0.01 & 0.0 & 0.932 & Air pressure & -0.54 & 16.2 & $* * *$ \\
\hline & Wind speed & 0.13 & 0.7 & 0.399 & Wind speed & -0.27 & 16.2 & 0.022 \\
\hline & Wind direction & & 2.5 & 0.292 & Wind direction & & 6.3 & 0.043 \\
\hline & Headwind & -1.12 & & & Headwind & -2.07 & & \\
\hline & Crosswind & -1.17 & & & Crosswind & -1.41 & & \\
\hline & Tailwind & -1.67 & & & Tailwind & -1.77 & & \\
\hline & $R_{\text {marg }}^{2}$ & 0.10 & & & $R_{\text {marg }}^{2}$ & 0.13 & & \\
\hline & $R_{\text {cond }}^{2}$ & 0.44 & & & $R_{\text {cond }}^{2}$ & 0.70 & & \\
\hline \multirow[t]{10}{*}{ Yellow-browed Warbler } & Temperature & 0.44 & 118.6 & $* * *$ & Temperature & 0.21 & 7.5 & 0.006 \\
\hline & Precipitation & 0.09 & 7.1 & 0.008 & Precipitation & -0.57 & 68.7 & $* * *$ \\
\hline & Air pressure & -0.14 & 16.4 & $* * *$ & Air pressure & -0.32 & 24.6 & $* * *$ \\
\hline & Wind speed & 0.08 & 6.6 & 0.010 & Wind speed & -0.45 & 71.3 & $* * *$ \\
\hline & Wind direction & & 46.1 & $* * *$ & Wind direction & & 27.6 & $* * *$ \\
\hline & Headwind & 0.98 & & & Headwind & 0.39 & & \\
\hline & Crosswind & 1.12 & & & Crosswind & 0.59 & & \\
\hline & Tailwind & 0.57 & & & Tailwind & 0.89 & & \\
\hline & $R_{\text {marg }}^{2}$ & 0.03 & & & $R_{\text {marg }}^{2}$ & 0.18 & & \\
\hline & $R_{\text {cond }}^{2}$ & 0.94 & & & $R_{\text {cond }}^{2}$ & 0.92 & & \\
\hline
\end{tabular}


Table 3 (continued)

Estimates refer to the slope related to the variables, but represent the mean for categorical variables (wind direction, in italics). Shown are test statistics, $R_{\text {marg }}^{2}$ (fixed factors alone) and $R_{\text {cond }}^{2}$ (fixed + random factor). $p$ values below 0.001 are marked as ***

in three out of four species. Wind direction is an important factor in all models, with most birds trapped during tail wind, and least birds during head winds. Air pressure was found to have minor impact on the numbers, but a negative relation was found in three out of four species.

\section{Discussion}

During our work, the effects of air pressure, rainfall, temperature, wind strength and wind direction were investigated for four species. We found strong impacts of weather variables on the number of trapped warblers during spring and autumn migration. Overall, preferred or avoided weather conditions were similar among the studied species, but some slight differences were found.

All species seem to migrate preferably during warm, calm days without precipitation in spring and autumn too. It is important to note that in case of intense rainy weather, mist-nets were closed for the safety of the birds, but there would certainly not have been a significant amount of bird in these days. The fact, that the maximum temperature is positively related with the number of trapped individuals in the overall model and in three out of four species is certainly associated with the timing of migration.

Previous studies have shown that the migration peak of most species coincides with days of high air pressure (Alerstam 1990; Gyurácz et al. 1997). On such days, there is constant sunshine and low temperatures. In Siberia, a high anti-cyclone reigns from September to April, with its centre near Lake Baikal. This Siberian cycle is often characterized by high air pressures above $1040 \mathrm{mb}$ and extremely low temperatures (Oliver 2005). In spring, however, the effects of cyclones are characterized by high precipitation and high temperature values. In contrast, air pressure was found to have minor impact on the numbers of trapped warblers both during spring and autumn migration, but a slight negative relation was found in three out of four species in autumn. This suggests that the studied species seem to migrate independently from the air pressure.

Both the strength and the direction of the wind can be decisive in the timing of migration (Elkins 1988). In stormy winds, mist-netting is not possible, but as during heavy rains, few birds are expected to fly during such conditions. Accordingly, the number of birds of all species and the strength of wind were negatively correlated in spring and autumn migration.

In autumn, in cases of a northerly wind (tail wind), birds are known to fly longer distances while exerting less energy (Emlen 1975; Bloch and Bruderer 1982; Gauthreaux 1982, 1991; Alerstam 1990; Richardson 1990). Accordingly, we would expect the highest numbers of migrating birds in autumn during northern tail winds and in spring during southern tail winds. However, a positive effect of tail winds was only confirmed in autumn. Tail winds were a good predictor in case of Dusky and Yellow-browed Warblers in autumn, which may support the weather hypothesis, according to which some authors explain the westward vagrancy of Siberian leaf warblers species by the effect of the weather (Baker 1977; Howey and Bell 1985; Baker and Catley 1987). It is interesting to note that in spring, most birds were trapped during cross winds (eastern or western winds). It seems likely, that the studied warbler species exhibit a loop migration, with their spring migration routes closer to the East Asian coasts, leading to a more longitudinal migration pattern (from east to west) in our study area during spring (Fig. 2). The Wood Warbler (Phylloscopus sibilatrix) and Willow Warbler (Ph. trochilus), well-studied European breeding species, show also loop migration (Gyurácz and Csörgő 2009; Jónás et al. in press), and a similar pattern was found for geolocator-tracked Siberian Rubythroats (Calliope calliope) along the East Asian flyway (Heim et al. 2018a).

Despite the significant impacts of the weather variables, most of the variation was explained by interannual differences and preferred migration timing. The studied species are likely mainly following their innate migration schedule. Consistent migration timing between years was also found for Emberiza buntings at our study site (Heim et al. 2018b). This might especially be true for spring migration, when competition is high to arrive early at the breeding grounds (Nilsson et al. 2013), which could force individuals to continue migration under sub-optimal weather conditions.

Global change is expected to significantly alter weather conditions in Far East Russia (Mokhov and Semenov 2016) and a better understanding of how these factors could influence migratory birds is urgently required.

\section{Conclusion}

During our work we found strong impacts of weather variables (air pressure, rainfall, temperature, wind strength and wind direction) on the number of trapped warblers during spring and autumn migration. Birds seem to migrate preferably during warm, calm days without precipitation, however, relationships between weather variables and the number of migrating individuals were much 


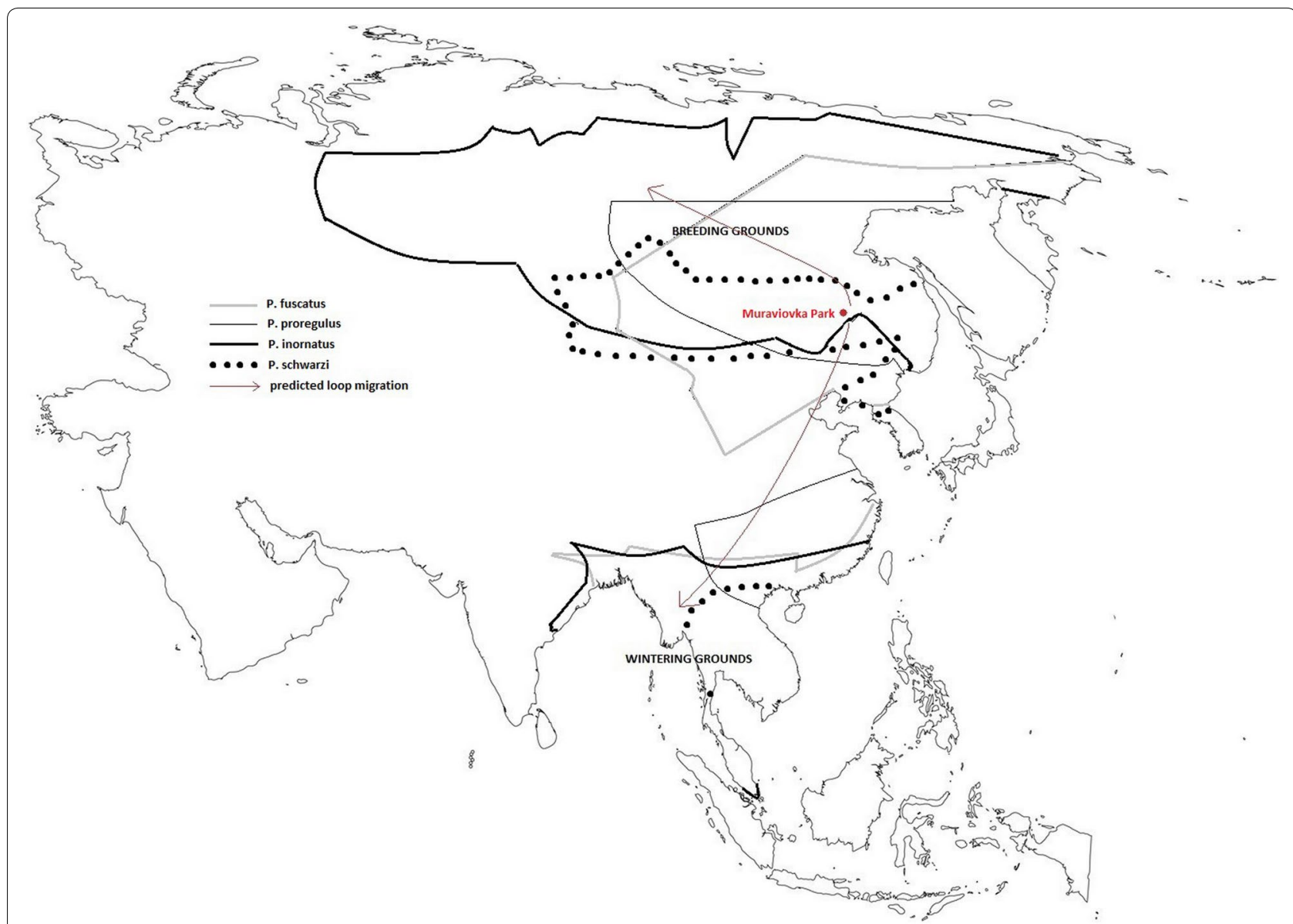

Fig. 2 Breeding and wintering grounds, and the supposed migration route of the study species. The study site (Muravovka Park) is also marked on the map. Distribution maps for each species based on The IUCN Red List of Threatened Species (2018)

stronger during autumn. Air pressure was found to have minor impact on the numbers of trapped warblers, while the strength and the direction of wind were important variables. Tail winds play an important role in autumn, but in spring migration was determined by cross winds, which indicates that the studied species might exhibit a loop migration.

\section{Authors' contributions}

LB and WH collected field data. TCS provided new ideas for this manuscript. $L B$ and WH performed data analyses. LB collected the weather data from the online dataset. LB wrote an early version of the manuscript. WH and TCS revised and improved the manuscript. All authors read and approved the final manuscript.

\section{Author details}

1 Department of Systematic Zoology and Ecology, Eötvös Loránd University, Pázmány Péter sétány 1/C, Budapest 1117, Hungary. ${ }^{2}$ Department of Anatomy, Cell- and Developmental Biology, Eötvös Loránd University, Pázmány Péter sétány $1 / C$, Budapest 1117, Hungary. ${ }^{3}$ Institute of Landscape Ecology, University of Münster, Heisenbergstraße 2, 48149 Münster, Germany.

\section{Acknowledgements}

The authors want to thank Sergei M. Smirenski and the staff of Muraviovka Park as well as the Amur Bird Project field teams for enabling these studies in Far East Russia. We kindly acknowledge the provision of rings by the Moscow Bird Ringing Centre, and thank Ramona J. Heim and Johannes Kamp for helpful comments on the statistical analysis.

\section{Competing interests}

The authors declare that they have no competing interests.

\section{Availability of data and materials}

The datasets used and/or analysed during the current study are available from the corresponding author on reasonable request.

\section{Ethics approval and consent to participate}

The authors confirm that all experiments were carried out under the current law for scientific bird ringing in Russia, and all necessary permissions were obtained.

\section{Funding}

The bird ringing program was supported by the German Ornithologists' Society, the Förderkreis Allgemeine Naturkunde (Biologie) e.V. and the NABU RVE e.V. LB's work was supported by the Campus Hungary Studentship and the Hungarian National Young Talent Studentship. 
Received: 8 April 2018 Accepted: 11 October 2018

Published online: 17 October 2018

\section{References}

Able KP. Fall migration in coastal Louisiana and the evolution of migration patterns in the Gulf region. Wilson Bull. 1972;84(3):231-42.

Able KP. The role of weather variables and flight direction in determining the magnitude of nocturnal bird migration. Ecology. 1973;54:1031-41.

Akesson S. Coastal migration and wind drift compensation in nocturnal passerine migrants. Ornis Scand. 1993;24:87-94.

Alerstam T. Analysis and a theory of visible bird migration. Oikos. 1978;30(2):273-349.

Alerstam T. Bird migration. Cambridge: University Press; 1990.

Arizaga J, Belda EJ, Barba E. Effect of fuel load, date, rain and wind on departure decisions of a migratory passerine. J Ornithol. 2011;152:991-9.

Baker K. Westward vagrancy of Siberian passerines in autumn 1975. Bird Study. 1977;24:233-42

Baker JK, Catley GP. Yellow-browed Warblers in Britain and Ireland, 1968-1985. Br Birds. 1987;80:93-109.

Bates D, Maechler M, Bolker B, Walker S. Ime4: linear mixed-effects models using Eigen and S4. R Package Version. 2014;1:1-23.

Berthold P. Control of bird migration. London: Chapman \& Hall; 1996.

Bloch R, Bruderer B. The air speed of migrating birds and its relationship to the wind. Behav Ecol Sociobiol. 1982;11:19-24.

Bowlin MS, Wikelski M. Pointed wings, low wingloading and calm air reduce migratory flight costs in songbirds. PLOS ONE. 2008;3:e2154

Bozó L, Heim W. Trapping and ringing Pale-legged Leaf Warbler Phylloscopus tenellipes, Muraviovka Park, Amur region, Far East Russia. BirdASIA. 2015:23:118-20.

Bozó L, Heim W. Sex-specific migration of Phylloscopus warblers at a stopove site in Far Eastern Russia. Ring Migr. 2016;31:41-6.

Bozó L, Heim W, Harnos A, Csörgő T. Can we explain vagrancy in Europe with the autumn migration phenology of Siberian warbler species in East Russia? Ornis Hung. 2016;24:150-71.

Bozó L, Heim W, CsörgőT. Spring and autumn migration of Pallas's Leaf Warbler Phylloscopus proregulus at Far East Russia. BirdingASIA. 2017;28:67-70.

Brazil M. Birds of East Asia. London: Christopher Helm; 2009.

Bruderer B, Boldt A. Flight characteristics of birds: I. Radar measurements of speeds. Ibis. 2001;143:178-204.

Bulte M, McLaren JD, Bairlein F, Bouten W, Schmaljohann H, Shamoun-Baranes J. Can wheatears weather the Atlantic? Modeling nonstop trans-Atlantic flights of a small migratory songbird. Auk. 2014;131:363-70.

Cochran WW, Kjos CG. Wind drift and migration of thrushes: a telemetry study. III NHS Bull. 1985:33:297-330.

Cochran WW, Wikeski M. Individual migratory tactics of New World Catharus thrushes: current knowledge and future tracking options from space. In: Greenberg R, Marra PP, editors. Birds of two worlds: the ecology and evolution of migratory birds. Baltimore: Johns Hopkins University Press: 2005. p. 274-89.

Deppe JL, Ward MP, Bolus RT, Diehl RH, Celis-Murillo A, Zenzal TJ, Moore FR, Benson TJ, Smolinsky JA, Schofield LN, Enstrom DA. Fat, weather, and date affect migratory songbirds' departure decisions, routes, and time it takes to cross the Gulf of Mexico. Proc Natl Acad Sci. 2015;112:E6331-8.

De Juana E. Where do Pallas's and Yellow-browed Warblers (Phylloscopus proregulus, Ph. inornatus) go after visiting Northwest Europe in autumn? An Iberian perspective. Ardeola. 2008;55:13-25.

Elkins N. Weather and bird behaviour. Calton: Poyser; 1988.

Emlen ST. Migration: orientation and navigation. In: Famer DS, King JR, Parkes KC, editors. Avian biology, vol. V. New York: Academic Press; 1975. p. 129-210.

Erni B, Liechti F, Underhill LG, Bruderer B. Wind and rain govern the intensity of nocturnal bird migration in central Europe-a log-linear regression analysis. Ardea. 2002;90:155-66.

Folvik A. Norwegian records of Yellow-browed Warbler Phylloscopus inornatus. Fauna Nor Ser C Cinclus. 1992;15:31-6.

Gauthreaux SA Jr. The ecology and evolution of avian migration systems. In: Farner DS, King JR, editors. Avian biology, vol. VI. New York: Academic Press: 1982. p. 93
Gauthreaux SA Jr. The flight behaviour of migrating birds in changing wind fields: radar and visual analyses. Am Zool. 1991;31:187-204.

Gill RE, Douglas DC, Handel CM, Tibbitts TL, Hufford G, Piersma T. Hemisphericscale wind selection facilitates bar-tailed godwit circum-migration of the Pacific. Anim Behav. 2014;90:117-30.

Gilroy JJ, Lees AC. Vagrancy theories: Are autumn vagrants really reverse migrants? Brit Birds. 2003:96:427-38.

Gyurácz J, Károssy C, Csörgő T. The autumn migration of sedge warblers in relation to weather conditions. Weather. 1997:52:149-54.

Gyurácz J, Horváth G, Csörgő T, Bank L, Palkó S. Influence of macrosynoptic weather situation on the autumn migration of birds in Hungary. Ring. 2003;25:17-36

Gyurácz J, Csörgő T. Sisegő füzike [Wood Warbler]. In: Csörgő T, Karcza Zs, Halmos G, Magyar G, Gyurácz J, Szép T, Bankovics A, Schmidt A, Schmidt E, editors. Magyar madárvonulási atlasz [Hungarian Bird Migration Atlas]. Budapest: Kossuth Kiadó; 2009. p. 519-20.

Harrop AJA. Eastern promise: the arrival of far-eastern passerine vagrants in autumn. Brit Birds. 2007:100:105-11.

Heim W, Smirenski SM, Siegmund A, Eidam F. Results of an autumnal bird ringing project at Muraviovka Park/Amur region in 2011. Avian Ecol Behav. 2012;21:27-40

Heim W, Pedersen L, Heim RJ, Thomas A, Smirenski SM, Tottrup A, Thorup K. Full annual cycle tracking of a small songbird, the Siberian Rubythroat Calliope calliope, along the East Asian flyway. J Ornithol. 2018a. https:// doi.org/10.1007/s10336-018-1562-z.

Heim W, Eccard JA, Bairlein F. Migration phenology determines niche use of East Asian buntings (Emberizidae) during stopover. Curr Zool. 2018b:1:2. https://doi.org/10.1093/cz/zoy016.

Howey DH, Bell M. Pallas's Warbler and other migrants in Britain and Ireland in October 1982. Brit Birds. 1985;78:381-92.

Jónás B, Harnos A, Csörgő T. Detection of Passerines' loop migration pattern using biometric data. Acta Zool Acad Sci Hung (in press).

Jiguet F, Barbet-Massin M. Climate change and rates of vagrancy of Siberian species to Europe. Ibis. 2013;155:194-8.

Kamp J, Oppel S, Ananin AA, Durnev YA, Gashev SN, Hölzel N, Mishchenko AL, Pessa J, Smirenski SM, Strelnikov EG, Timonen S, Wolanska K, Chan S. Global population collapse in a superabundant migratory bird and illegal trapping in China. Conserv Biol. 2015:29:1684-94.

Kerlinger P, Moore FR. Atmospheric structure and avian migration. In: Current ornithology, Springer; 1989. p. 109-42.

Krüger T, Dierschke J. The occurrence of Yellow-browed Warbler Phylloscopus inornatus in Germany. Vogelwelt. 2004:125:41-52.

Lefcheck JS. piecewiseSEM: piecewise structural equation modelling in R for ecology, evolution, and systematics. Methods Ecol Evol. 2016;7:573-9.

Liechti F. Birds: blowin' by the wind? J Ornithol. 2006;147:202-11.

Miller RA, Onrubia A, Martín B, Kaltenecker GS, Carlisle JD, Bechard MJ, Ferrer M. Local and regional weather patterns influencing post-breeding migration counts of soaring birds at the Strait of Gibraltar, Spain. Ibis. 2016:158:106-15.

Mokhov II, Semenov VA. Weather and climate anomalies in Russian regions related to global climate change. Russ Meteorol Hydrol. 2016:41:84-92.

Newton I. The migration ecology of birds. New York: Academic press; 2008.

Nilsson C, Klaassen RHG, Alerstam T. Differences in speed and duration of bird migration between spring and autumn. Am Nat. 2013;181:837-45.

Oliver J. Encyclopedia of world climatology. New York: Springer; 2005.

Pennycuick CJ, Battley PF. Burning the engine: a time-marching computation of fat and protein consumption in a $5420 \mathrm{~km}$ non-stop flight by great knots, Calidris tenuirostris. Oikos. 2003:103:323-32.

Phillips J. Autumn vagrancy: "Reverse migration" and migratory orientation. Ring Migr. 2000;20:35-8.

Pyle P, Nur N, Henderson RP, De Sante DF. The effects of weather and lunar cycle on nocturnal migration of landbirds at Southeast Farallon Island. California. Condor. 1993;95(2):343-61.

R Core Team. R: a language and environment for statistical computing. R Foundation for Statistical Computing, Vienna, Austria. Version 3.4.2. 2017

Rabøl J. Reversed migration as the cause of westward vagrancy by four Phylloscopus warblers. Brit Birds. 1969;62:89-92.

Richardson W. Timing of bird migration in relation to weather: updated review. In: Bird migration. Berlin: Springer; 1990. p. 78-101. 
Sander MM, Eccard JA, Heim W. Flight range estimation of migrant Yellowbrowed Warblers Phylloscopus inornatus on the East Asian Flyway. Bird Study. 2017;64:569-72.

Schaub M, Liechti F, Jenni L. Departure of migrating European Robins, Erithacus rubecula, from a stopover site in relation to wind and rain. Anim Behav. 2004;67:229-37.

Shamoun-Baranes J, van Gasteren H. Atmospheric conditions facilitate mass migration events across the North Sea. Anim Behav. 2011;81:691-704.

Shamoun-Baranes J, Liechti F, Vansteelant WM. Atmospheric conditions create freeways, detours and tailbacks for migrating birds. J Comp Physiol. 2017;203:509-29.

Svensson L. Identification guide to European passerines. Stockholm: Svensson; 1992.

The IUCN Red List of Threatened Species. Version 2018-1. www.iucnredlist.org. Downloaded on 08 August 2018.

Thorup K. Vagrancy of Yellow-browed Warbler Phylloscopus inornatus and Pallas's Warbler Ph. proregulus in north-west Europe: Misorientation on great circles? Ring Migr. 1998;19:7-12.
Thorup K. Reverse migration as a cause of vagrancy: capsule reverse migration in autumn does not occur to the same degree in all species of migrants, but is related to migratory direction. Bird Study. 2004;51:228-38.

Van Belle J, Shamoun-Baranes J, van Loon E, Bouten W. An operational model predicting autumn bird migration intensities for flight safety. J Appl Ecol. 2007:44:864-74.

Weber TP, Hedenström A. Optimal stopover decisions under wind influence: the effects of correlated winds. J Theor Biol. 2000;205:95-104.

Williams MD. Autumn bird migration at Beidaihe, 1986-1990. Beidaihe: Beidaihe International Birdwatching Society; 2000.

Woodworth BK, Mitchell GW, Norris DR, Francis CM, Taylor PD. Patterns and correlates of songbird movements at an ecological barrier during autumn migration assessed using landscape- and regional-scale automated radiotelemetry. Ibis. 2015;157:326-39.

World Weather Online. http://www.worldweatheronline.com. Data download at 20 Dec 2017.

Xu Y, Lin S, He J, Xin Y, Zhang L, Jiang H, Li Y. Tropical birds are declining in the Hainan Island of China. Biol Conserv. 2017:210:9-18.
Ready to submit your research? Choose BMC and benefit from:

- fast, convenient online submission

- thorough peer review by experienced researchers in your field

- rapid publication on acceptance

- support for research data, including large and complex data types

- gold Open Access which fosters wider collaboration and increased citations

- maximum visibility for your research: over $100 \mathrm{M}$ website views per year

At BMC, research is always in progress.

Learn more biomedcentral.com/submissions 